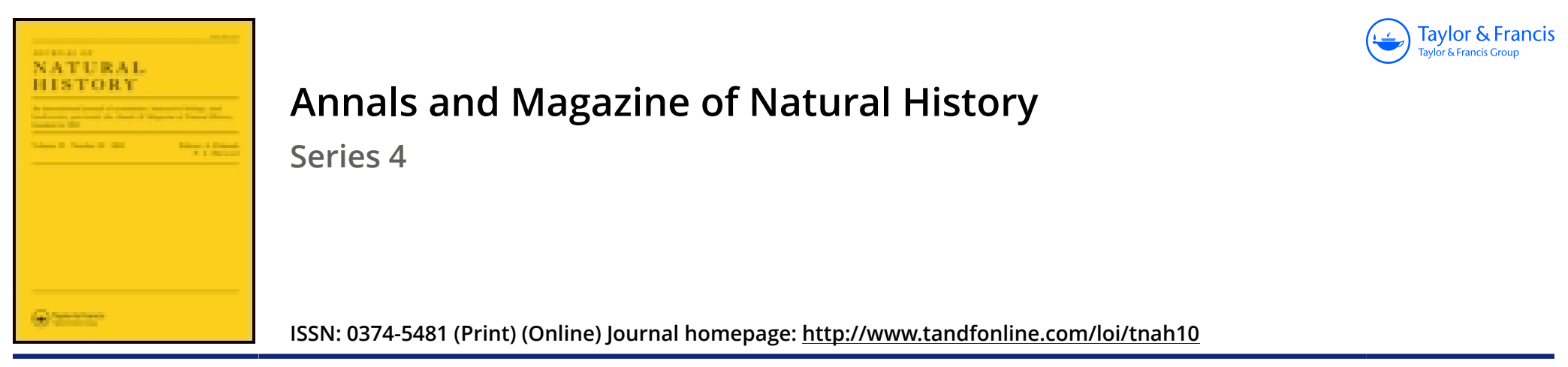

\title{
XXII.-On some new fundamental principles in the morphology and classification of Rhynchota
}

\section{Professor J.C. Schiödte}

To cite this article: Professor J.C. Schiödte (1870) XXII._On some new fundamental principles in the morphology and classification of Rhynchota, Annals and Magazine of Natural History, 6:33, 225-249, DOI: 10.1080/00222937008696238

To link to this article: http://dx.doi.org/10.1080/00222937008696238

\section{Published online: 19 Oct 2009.}

\section{Submit your article to this journal $\square$}

Џ Article views: 2

Q View related articles $\square$

Citing articles: 1 View citing articles $\square$ 


\section{XXII.-On some new Fundamental Principles in the Morpho- logy and Classification of Rhynchota. By Professor J. C. SCHIÖDTE*.}

\section{I.}

In all the large independent works, as well as in the numerous minor treatises, by which Latreille has founded the natural system of the articulated animals, there is an undercurrent of merely indicated scientific views, which he has abstained from working out, either because time and material failed him, or because he lacked the necessary courage and confidence in his own ability to get over some mistake of observation, often an entirely accidental one, which had stopped his progress. Thus, for instance, his exceedingly ingenious theory of the "segment médiaire," which, rightly understood, solves so many hard morphological knots, and is of such comprehensive and useful application in classification, has had the fate of being rejected by such anatomists as Burmeister, Westwood, Straus-Dïrckheim, Lepelletier de St. Fargeau, Newport, Spinola, and Lacordaire, only because he was unable to supply that conclusive element which was required to give it scientific certainty and support it by decisive proof-namely, the demonstration of the apparently missing pair of spiracles between the second and third thoracic rings in Piezata $\dagger$. There are other cases where Latreille has incidentally pointed out the importance of certain features in the structure of insects which are more easily investigated, and where these indications, which the great French naturalist had left undeveloped, have been investigated by subsequent authors; but they have rarely done more than accumulate descriptive details. As an example we may adduce a passage in 'Le Regne Animal ' (nouv. ed. 1829, tom. iv. p. 306), where, after having treated of the relation between the epimera and the segments of the body, he continues in this manner:- "Les relations de ces parties, la grandeur et la forme du premier article des hanches, la manière dont elles s'articulent avec le demi-anneau dont elles dépendent, l'étendue et la direetion de ce demi-anneau variant, le thorax considéré sous ce point de vuc, présente une combinaison de caractères, qui est très avantageuse pour la methode." The indication of the differences in the mode of articulation of the limbs with the body which is contained in these words was never more fully

* Translated from 'Naturhistorisk Tidsskrift,' ser. 3, vol. vi. 1869. Copenhagen.

$\dagger$ See 'Proceedings of the Royal Danish Society of Sciences, 1856, p. 135.

Ann. \& Mag. N. Hist. Ser.4. Vol. vi. 
developed by Latreille. Later zootomists and systematic authors, particularly Spinola and Erichson, have certainly occasionally turned their attention to the coxæ of Eleutherata, and distinguished between coxæ globosæ, transversæ, and conicæ. But these distinctions, which only take into consideration the external form, are in themselves superficial, and lack the desirable sharpness and certainty of application, even when considered from the merely descriptive and diagnostic point of view-because coxæ globosæ, by a gradual elongation downward, insensibly become coxæ conicæ, and by lateral extension at last coincide with coxre transversæ, whilst the latter, when inclined inwards and downwards, become undistinguishable from coxæ conicæ. Besides, coxæ of each of these forms may be more or less moveable, and there is an insensible transition between those which are deeply inserted into sockets of articulation and those which are more superficially fixed; in consequence of which the distinction which now and then is made between coxæ fixæ and coxæ mobiles, not only does not state any thing about the mode of movement, but is without connexion with the distinctions made with regard to form. These distinctions, therefore, however useful they may be within a limited systematic division, do not touch the central point of the question, which I hope to be able to place in a clear light by the following considerations.

The limbs of Articulata articulate with the body in two principal ways, corresponding to two fundamental forms of coxa-coxce cardinatce and coxce rotatoriae.

Coxa cardinate * are either immoveably connected with the body, or they can only be moved slightly from side to side, or backwards, in the direction of the longitudinal axis of the animal. The mobility being reduced, the epimera and the sternum, which are intended to contain the muscles serving for the movement of the coxæ, are correspondingly reduced in size, whilst the coxa itself, which in this case alone has to accommodate the muscles which move the remainder of the leg, becomes more expanded and capacious in the same proportion. Where powerful movements are executed in a horizontal plane, by which the leg at the same time describes a. large arc, particularly in running or swimming, the large coxa is furnished with a groove (scrobiculus femoralis) on its external surface, in order to obtain space for the bending forward of the leg.

Coxoe rotatorice can be turned round their own longitudinal

* This expression is borrowed from Vitruvius (in the paper "De aliis testudinibus," Schneider's edition, i. 301). 
axis. In this case the muscles which move the coxæ always demand more space, and in the same proportion the epimera and the sternum are increased in size. The coxa itself being rendered more independent of the neighbouring parts by its greater mobility, may and does vary considerably in size, but retains always a rounded shape, and is always fitted in a deeper socket. In legs serving the purpose of walking, the rotatory coxa is frequently very small and reduced to a mere node of articulation for the remainder of the leg, whilst its size is often very considerable where the legs are used for running or swimming, and still more in fossorial legs. In the former case the coxæ will be separated by a considerable interval, and placed so near the sides of the animal that the movement of the leg becomes sufficiently clear of the body; and no groove will then be necessary for facilitating the bending forward of the leg. But in the latter case the coxæ must meet in the middle, as the large cursory and natatory forms of coxæ cardinatr; and a groove will then be necessary also in the case of coxæ rotatoriæ. Typically, however, this combination is as much calculated for walking as that of the coxæ cardinatæ is calculated for running, springing, and swimming.

Both forms of coxa may occur in the same animal, particularly in this way--that only the foremost or some of the foremost pairs of limbs have rotatory coxæ. When those limbs which serve for the progression of the animal have cardinate coxæ, the animals may be described as Pagiopoda; but when the progression of the body depends on limbs with rotatory coxæe, we may describe them as Trochalopoda.

The great majority of Articulata of all three classes are Pagiopoda in a great variety of modifications, in many cases affording excellent characters for natural divisions, which have not yet been made use of, but which cannot be further explained in the present treatise. A considerable number of Eleutherata and Rhynchota are Trochalopoda; and it is with regard to the latter of these orders that the whole subject has been mooted here, because, when combined with certain other elements of structure which have likewise hitherto been overlooked or not rightly interpreted, they may serve for a more natural classification than that which has hitherto been adopted.

\section{II.}

The classification of Rhynchota stands in scientific respects still at the same point at which it was left by its founders, Fabricius and Latreille; it is scarcely possible to point out any new or fruitful idea which has been applied to it since. 
At the same time, this order has, during the last two or three decennia, been worked up with predilection by a number of specialists, to whose untiring and in part very meritorious exertions we are indebted for an astonishing increase in the number of described species. The isolated merely descriptive treatment of the contents of the different museums, however, has had its usual consequences: the classification has become a mere register of specific characters; the distinction between its categories has been rendered evanescent; and it has ceased to reflect the typical unity of the morphological variations. So far from the true understanding of the structure and life of the animal having been furthered, the state of our knowledge, on the contrary, as may be seen by consulting the newest and most used manuals, has receded several steps behind the standpoint to which the leading works of thirty years ago had brought it. In the following, however, we shall confine our investigation of the present classification to those cardinal points which come into consideration in establishing the scheme which we propose.

The very first point in the morphology of Rhynchota, which is of primary systematic importance, is erroneously stated by all the authors that I am acquainted with.

The two natural suborders Homoptera and Hemiptera are in their whole habitus so distinct that even the most superficial investigation cannot fail to appreciate their difference; and the perception of these two suborders can be traced in the writings even of the very earliest naturalists. But it was found that a suitable diagnosis of their difference could not be obtained by means of the changeable forms of the wings; and it was then proposed to distinguish them by means of the place of insertion of the rostrum, which was supposed to be fundamentally different in the two orders, of which accordingly one, the Heteroptera, often were described as Frontirostria, whilst Homoptera were described as Gulcerostria. In the former case the rostrum was supposed to take its origin from the epistoma, in the second case from the underside of the headhypostoma. This view is undoubtedly at variance alike with common sense and the first elements of a scientific appreciation of the structure of the head in Articulata. It is true that it has been adopted by men of scientific spirit and knowledge, like Latreille, Dufour, Burmeister, and others, who cannot possibly have been ignorant of the fact that the parts of the mouth in all cases have their basis on morphologically the same parts of the head, whatever position these parts may occupy in the general outline of the animal, according to the exigencies of its structural combinations. But these zoolo- 
gists evidently thought that they might content thernselves with treating the matter from the point of view of simple horismology, and that, at any rate, the distinction practically worked so well that a morphologically true character might be dispensed with, just as ichthyologists are content to say that the mouth in Sturgeons and Plagiostomata is placed on the under surface of the head. But the fact is that the definition does not hold good even if it is understood in a purely horismological sense-that is, even if the parts are named without regard to their morphological value. Between the structure of the Reduvii, where the rostrum appears as an immediate continuation of the top of the head, and that of Cicadae, where it closely adjoins the prosternum, there is a series of insensible transitions, represented by the swimming species, as well as by many living on the land, such as the Platycephala; and the whole question about the so-called position of the rostrum resolves itself into this, that the forehead is more or less bent in under the head. The distinction hitherto supposed to be expressed in the position of the rostrum is as untenable as that derived from the wings; and the diagnoses of the two suborders have become so loose and indefinite, and, by additional explanations and restrictions so prolix, that, in the new manual of Fieber on the European Rhynchota-fauna (a volume in large octavo), they fill respectively nine and sixteen closely printed lines in small type. There is evidently here a serious defect in our knowledge. Unless a clear and welldefined mark of distinction between the two suborders can be found which is connected with their mode of life and expresses a morphological difference, it is far better to unite them : the present uncertain and tentative mode cannot satisfy any body.

It is evident that the rostrum must correspond to the food. But the sharply defined varieties of form and the manifold combinations of division of labour which solid food, by its varying degree of resistance to prehension, division, and deglutition, necessitates in the appendages of the mouth are, as a matter of course, only to a small extent observable in Rhynchota, which only live upon organic juices, animal or vegetable. The rostrum naturally varies to some extent in strength, length, curvature, stiffness, \&c., according to the nature of the surface which has to be perforated before the nutritious liquid is reached; but we cannot expect to find any sharp lines of demarcation between these different forms, because when the animal has got hold of the body to be perforated, the work to be performed by the pungent instrument will always be essentially the same. But it is quite different with those organs which are to enable the animal to find the suitable surface, 
reach it, and get it in its power. Whether the animal runs about hunting living game, and keeps it by force whilst sucking out its blood, or slinks from place to place as a parasite on the skin of another animal, or remains immovable for days and weeks on the same part of a plant, in lazy sociability, and fills itself with the juice, these are differences in the mode of life which must be accompanied by corresponding differences in the organs of sense and movement; and we find accordingly that Rhynchota vary in this respect to a very great extent, whilst they exhibit a striking uniformity in the structure of their mouth. Similar conditions of life occur in Antliata. But whilst in Antliata the structure of the imago, on account of the complete metamorphosis, is more exclusively calculated to serve the propagation of the species, the structure of the adult animal in Rhynchota is equally determined by the exigencies of the propagation of the species and the nutrition of the imago itself. Hence arises the overwhelming, teeming multitude of different forms, in which Rhynchota surpass all other orders of insects, and which renders the interpretation of their morphology and their classification a task of so great difficulty and intricacy that entomologists have preferred to evade it instead of attempting a solution of it, and carried the subdivision so far that their efforts at recognizing the types of these animals have ended in the suicidal result of considering very nearly each species to represent a generic type by itself. But although, as we have just explained, such variation in the structure of the mouth as we meet with in animals which catch and masticate their food by means of the appendages of the mouth cannot be expected in sucking animals like the Rhynchota, it cannot, on the other hand, be supposed that the great difference which upon the whole must exist between animals which exclusively live on vegetable juice, such as exclusively feed on animal juices, and those, finally, which partake of both kinds of nourishment, would not, in the midst of all this richness in form, be marked by some decisive and distinctive anatomical feature. More particularly we may confidently assert that the quiet expanded surface of the plant demands quite other properties in the structure of the Rhynchoteous animal than the sharply defined, plastic, rounded body of the living animal writhing and turning about under the attack of the blood-sucker. In both cases strength in directing the thrust of the rostrum is required, particularly in the former case; but there is one provision required by the blood-sucker, which would be most injurious to the sucker of vegetable juices; and that is, facility in changing the aim of the rostrum during use, particularly as many blood-suckers 
first kill and then suck, and consequently must often repeat the thrust. In this latter case the whole figure must be slimmer, the head smaller and susceptible of lateral and rotatory movements, whilst the shape of the head and rostrum for the rest may vary very considerably according to the nature of the prey. But in the former case the general figure of the animal will naturally be shorter, more thick-set; the head, more particularly, will be larger, because it is to accommodate the more powerful muscles required for penetrating the firmer vegetable surface; while at the same time there is no need of the head being capable of turning to the side or round its longitudinal axis, nor is there any occasion for considerable variations in the form of the head or the rostrum, as these animals can always assume essentially the same position in the act of perforation and suction.

The blood-suckers, moreover, require principally fitness for running and walking, whilst those which live on vegetable juices want adaptation for springing and flying. On closer examination, this circumstance will supply us with the true key to that difference in habitus between Heteroptera and Homoptera which has been dimly recognized almost from the beginning, but which entomologists have not yet been able to express satisfactorily in their diagnoses, though in practice they have rarely erred in referring any particular species to one or the other of these suborders. The reason why the difference in question has not yet found a satisfactory expression in systematic diagnoses, is this-that in proportion as the Heteropterous type is accommodated for subsistence on vegetable juices, it is as it were veiled by an imitation of the Homopterous cicadarian type. The main point is, that in the phytophagous type of Rhynchota the head is so modified in shape as to enable it to receive support from the prothorax; for the thrust of the rostrum cannot be executed with collective force if it is directed out from the body of the animal; the requisite force is obtained only when the thrust is directed inwards, supported by the weight of the animal and its firm footing on the surface in question. Therefore the rostrum is always directed backwards; and when the animal is to become exclusively phytophagous, special arrangements become necessary in order to render this direction the only one possible, so that the whole power may be concentrated in this direction only.

The broad and flat form of the head of the Cicada, which is not capable of turning, is imitated by the head of bugs, which are not exclusively blood-suckers, although their head is always capable of turning. The imitation consists in this, that the 
head, without augmentation of its inner capacity, is increased in size by expansion of its margins-a plan which entails similar expansions of the prothorax and, at least in part, of the following body-segments. In such bugs as, for instance, Cimices and Corei, including Tingides and Aradi, head, thorax, and abdomen may have the appearance of considerable size, and a shape reminding one of the Cicada, whilst, in reality, with regard to space for the soft parts of the body, they are not larger than the slimmest Reduvii. But in spite of the expansion of the margins, the lateral and rotatory movements of the head, which are conditions of carnivorous habits, are not much curtailed, because the neck retains its shape. In Homoptera this is different: the head is really as large (that is, as capacious) as it appears outside. Here, then, we have got at a fundamental difference, which may be obscured to the more superficial consideration, but which in its nature must be thoroughgoing, and which in reality expresses itself with all desirable sharpness in a certain feature of external structure. In order to cause the two contrary movements, viz. the pressing backwards of the head and the rostrum and the pressing forwards of the body, to cooperate under the most favourable conditions by the diminution of the distance between their starting-points, the forehead is bent so far in under the animal that a struggle for space, so to say, arises between the head and the fore legs, which only can be solved by a compromise, namely thereby, that the coxæ of the fore legs to a certain extent are accommodated in the head, in excavations of the cheeks, which consequently, though it sounds absurd, really take part in the formation of the articular socket of the first pair of coxæ. By this arrangement it becomes, of course, impossible for Homoptera to turn their head during perforation or suction; they are unable to do more than to raise or depress it a little. In Heteroptera no such thing takes place, however broad and flat their head may appear : the cheeks only reach to the prosternum, but never so far as the front legs, and the head therefore retains its capability of turning on the protracted cervical process. These facts, then, lead to the following diagnosis of the two suborders:-

Homoptera. First pair of coxæ articulate with the cheeks. Heteroptera. Cheeks and first pair of coxæ do not touch each other.

\section{III.}

All Homoptera are Pagiopoda and phytophagous; they exhibit a great variety of forms, which, however, all range 
themselves into one series, proceeding without lateral branches from $\mathrm{Cocci}$ to the true Cicada, in one and the same direction, the lowest stage being characterized by sedentary habits (with propagation during summer without previous development of sexes), the higher ones by different degrees of fireedom of movement-particularly springing and flight, and various combinations of these two modes of movement, which necessitate special developments of head and thorax as instruments of balance, causing the fantastic appearance of many Fulgoridæ and Membracidæ.

Amongst Heteroptera, on the other hand, some are exclusively blood-suckers; others subsist both on vegetable and on animal juices; and they exceed therefore the Homoptera in variety of form. Some are 'Trochalopoda, others Pagiopoda.

The coxæ of trochalopodous Heteroptera are round and, at least on the outer side, embraced by a projecting margin of the metathorax, which corresponds to their outline, whereby a proper socket is formed. These Trochalopoda comprise two great divisions-those which feed on mixed food, and the pure carnivora.

A. Trochalopodous Heteroptera living on mixed food.--The tendency to expansion and thick-set structure which we have explained above as characteristic of phytophagous habits, shows itself here, even in the slenderest species, also in the metathorax, which has the appearance of a plate, of which the pasterior margin forms a projection of varying extent, beyond the first abdominal segment. By degrees, as carnivorous habits prevail, the lateral edges of the body are less expanded, and we observe a gradual transition from the short angular bug-type with elliptic transverse section to the elongated oval shape with even lateral margins and increasing depth of body. This series of bugs has been broken up by systematic authors into a number of small families, mostly based on general habitus, but in part also based on the number of joints in the feet and in the rostrum. But the number of tarsal joints may be different in species otherwise nearly allied, and the tube of the rostrum is in reality four-jointed in all Rhynchota; when they are sometimes said to have a rostrum of a less number of joints, this really only means that the basal joints are small, partly hidden by the projecting parts of the forehead, and not counted. I consider it far more natural to determine the steps of this series by the position of the antennæ, which depends on the different degree and the direction of the expansion of the head-that is, by the marks pointed out by Fabricius and Latreille,-the antennæ being either inserted 
under the margin of the forehead or free at their insertion, and in the latter case inserted either at the top of the head, in the same line as the eyes, or below the eyes on the sides of the head. Thus we arrive at three large families-Cimices (with Tetyree and the fossorial group of Cydnini), Corei (with Aradi and Tingidce), and Lygaei. It is only within the latter family that predatory habits so far predominate that the first pair of limbs are sometimes developed into instruments for catching the prey.

B. Puvely carnivorous trochalopodous Heteroptera.--The whole structure is calculated for freer movements ; the projecting margin of the metathorax is wanting, and the root of the abdomen is entirely uncovered. The first pair of legs are generally adapted for catching the prey. This series of bugs, too, has been divided into a number of small families, and they have in part been mixed with those of the preceding series and with Pagiopoda. This group may naturally be divided in a manner corresponding with the local circumstances of life. Reduvii (with Syrtis and Nabis), which live on dry land, have terminal claws; Hydrometre, which run on the surface of water, have the claws inserted above the point of the foot, and are, at least on the ventral surface, clothed with an aëriferous felt. Both families consist of animals living in atmospheric air, and have free antennæe and spiracles. Those of the third family, Nepee, climb or row under water, and have short antennæ hidden under the cheeks; their spiracles are by special contrivances secured against the entrance of the water; and the last pair is transformed into a long respiratory tube.

The triangular posterior coxæ of the pagiopodous Heteroptera join the metathorax with the whole of their open base, and occupy its posterior margin ; they reach, consequently, as far out to the sides as the metathorax, but a part of their real extent is sometimes hidden by the margin of the metathorax forming a flat projection which covers their external part, without, however, embracing the coxa as in Trochalopoda. The Pagiopoda are all blood-suckers. From the morphological point of view, these, therefore, repeat the series of forms observed in Trochalopoda-but with this difference, that the basis of the abdomen is naked. Recent authors, not being aware of the important character which binds them together, have split them into a great number of small families, and mixed them up with Trochalopoda. According to the localities in which they live, they are divided into:-Acanthioe (Capsus and Miris, Anthocoris, \&c., and Xylocoris, Salda, Leptopus), with free antennæ; Pelegoni, living on shores, with hidden 
antennææ and cursorial limbs ; and swimming-bugs, with hidden antennæ and swimming-legs. The latter are again divisible into those which swim on their back (Notonecter), boat-shaped, and with free rostrum, and those which swim in the usual position, which again are divisible into Naucorides, with free rostrum and free metathorax, Belostomata, with free rostrum and the sides of the metathorax covered by the overreaching lateral parts of the mesothorax, and Corixce, with hidden rostrum and free metathorax. The family of Acanthioe comprises species indicating, so to say, the developments of the type into the other families: Pelegoni more particularly are indicated by Salda. For the rest, it is still doubtful whether Pelegoni and Naucorides can be sharply distinguished from each other.

In trochalopodous as well as in pagiopodous Heteroptera, the articulation of the abdominal segments is in the same degree more moveable as the structure is more exclusively calculated for carnivorous habits, particularly when the animal lives under circumstances which in themselves require greater flexibility of the body, for instance, in the water, or hunting on plants; but if it seeks its prey on an open and even surface, the abdomen may be as inflexible as in suckers of vegetable juices. Thus the joints coalesce along the middle of the ventral surface, not only in many Cimices, but also in many Reduvii. In many Lygoi, in Nepoe, Nabis, Anthocoris, \&c. the edges of the anterior segments meet on a level, whilst the posterior segments are imbricate; but in Capsi all the joints are imbricate, and the whole abdomen very moveable, \&c. These differences afford in several instances useful marks for groups and genera.

The Rhynchota, which live as parasites on warm-blooded animals and possess a telescope-formed rostrum, are pagiopodous, but must, in accordance with their general structure, be treated as a separate division, Siphunculata (Latr.), of equal value with Heteroptera and Homoptera.

\section{IV.}

The classification to which the views explained in the foregoing necessarily leads entails, in several respects, such a thorough revolution in the hitherto received arrangement, that it can scarcely look for ready and immediate acceptance by hemipterologists. But nothing will offend them more than the demolition of the division of Cryptocerata, which hitherto has been looked upon as irremoveably established. This division as now accepted is remarkable for uniformity in general appearance, and possesses an easy and decisive character in the short and hidden antennæ; it will there- 
fore, first of all, be objected to my classification that it dissolves a natural division which has been long recognized as such, and that it does away with the generally accepted distribution of Heteroptera in Geocores and Hydrocores. My answer is that Cryptocerata (Pelegoni, Nepce, Naucorides, Corixa, Notonectce) are not united together except by features which are connected with their life under water, and that Nepoe on the one side, and Notonectre and the other families on the other side, are not less different from each other in all points of their structure than Dytisci and Hydrophili amongst Eleutherata. In Nepce the posterior limbs are moved alternately, as in Hydrophili; like these latter, they crawl and climb and row about; and in both families peculiar modifications of certain organs are required in order to facilitate respiration-in Hydrophili of the antennæ, in Nepee of the last pair of spiracles: in Naucorides, Corixae, and Notonectee, on the contrary, the movement of the posterior limbs is isochronic, as in Dytisci; they are like these typical swimmers; and no special arrangements are required for the sake of respiration, as the surface of the water can always be reached without difficulty, not to mention that the highest-developed water-bugs swim with the ventral surface upturned. I anticipate an objection to this-namely, that Cryptocerata show themselves to form a natural division in the structure of the thorax, being the only division of Heteroptera with separate epimera. But this is simply an error: Cryptocerata have undivided thoracic segments like all other Rhynchota; a real open seam between sternum and epimera is never to be found. Nor is it difficult to trace the origin of the mistake. The fact is that each group of muscles belonging to the limbs moulds that part of the thorax to which it is attached into a separate form; and the lines of demarcation between these divisions project internally in proportion as the muscles are stronger; these boundarylines appear outside as slightly impressed lines, and, on account of their thickness in the depth, they appear with a darker colour when the background is light. The water-bugs, being supported by the medium in which they live, do not require such thick integuments of the thorax as those which live on dry land; their colours are never very dark, never metallic, but generally grey or yellow, in consequence of which the integuments are more even, smooth, and lamelliform than in land-bugs, and the boundary-lines between the parts occupied by different sets of muscles far more striking to the eye. It is likewise an erroneous appreciation of facts when it is stated that the metathorax in Corixae is furnished with "parapleuræ" (that is, epimera separate from episterna); for the coxæ do notatallarticulate with 
these "parapleuræ," which are nothing but lamelliform projections of the metathorax itself, separated by an indentation, which serves to get more space for the bending forwards of the posterior limb. Nor is this projection peculiar to Corixa, for it occurs also in Salda - that is, in quite a different division from Cryptocerata.

How entirely entomologists have allowed themselves to be guided in the arrangement of this division by superficial impressions of general similarity, is evident from the fact that Naucoris, merely on account of the oval shape and the strong development of the anterior legs for catching prey, has been placed between Pelegoni and Nepoe, and separated still further from Corixce, its nearest relatives, by the interposition of $\mathrm{No}^{-}$ tonectee (see M. Fieber's paper, "Genera Hydrocoridum secundum ordinem naturalem in familias disposita:" Pragæ, 1851, 4to). But, above all, the juxtaposition of Nepoe and Belostomata in one and the same family shows that classification here has only been founded on superficial similarities. Burmeister, who, like the majority of earlier authors, even reckons Naucoris amongst Nepa, and states that all water-bugs of this family respire through tubes which project from the apex of the abdomen, is obliged to add that these respiratory tubes are wanting in many Nepoe, particularly in the males, and that they are also wanting in the larvce (see 'Handb. d. Entomologie,' ii. 192, 195). Fieber attempts, in the paper just quoted, to bring about uniformity in this respect by stating that the so-called respiratory tubes of Nepoe do not serve for respiration, but are genital appendages; whilst in his work on the European Hemiptera-fauna, he states that these tubes belong to the genitalia in Belostomata, but are of a different, not yet discovered, nature in Nepa and Ranatro. The truth is that these appendages are fundamentally different in nature and origin in the pagiopodous Belostomata, where they belong to the genitalia, and in the trochalopodous Nepo, where they are respiratory tubes. Just as the medium in which the animals live and move requires short antennæ and a felt covering of the ventral surface in all water-bugs, whatever be their typical differences, so a parallelism may be observed also between other modifications of different types of waterbugs ; with regard to Nepce and Belostomata, we observe it besides in these points- that the side of the metathorax in both is covered by the lateral part of the mesothorax, and that in both the ramified antennæ serve as air-reservoirs.

$$
\mathrm{V} \text {. }
$$

We arrive here at a point of structure which is still shrouded 
in great obscurity, namely the number and position of the spiracles in Heteroptera. Scarcely two authors agree on this subject; and there is no vestige of any one having so much as thought of any fixed rule being observable in this respect.

If, for instance, we turn to the newest manual * (Fieber's well-known and indispensable work on the Rhynchota of Europe), we read (p. 9) that "The spiracles of the body, stigmata, appear only now and then clearly on the dorsal rings, and are, with the exception of some genera of Hydrocorides, always to be perceived on the sides of the ventral surface as small perforated knobs (Taf. i. fig. $30, i$ ). The spiracles of the thorax are placed on the sides of the metathorax, and show an elongated slit, surrounded by a thick or lamelliform margin (Taf. i. figs. 1, 2, 30, p), which sometimes terminates on the outer side in a corniform prolongation (some Berytidi, Oxycareni). More rarely, each segment of the thorax has its own spiracle." A little before, in treating of the prothorax (p. 7), it is stated :- "The prothorax rarely has a spiracle"; and in treating of the abdomen (p. 8), "The connecting marginal piece, connexivum, which is turned round from the ventral surface to the back (Taf. ii. fig. $2, b$ ), carries the dorsal stigmata, which in Nepa particularly clearly are covered by a membrane." According to the statement on p. 8, the stigmata of the abdomen are situated on the dorsal surface; according to p. 9, sometimes on the back, but always on the ventral side; the thorax, we are to understand, has only sometimes spiracles between the prothorax and mesothorax, more rarely a pair for each segment, but always a pair on the metathorax. Any reader, however, who understands that the last statement contains a physiological impossibility, and therefore examines M. Fieber's figures in order to obtain further information, will easily perceive, if he is at all conversant with the anatomy of Rhynchota, that what the author represents as spiracles are no spiracles at all, but simply the orifices of the odoriferous glands. It is an old error, and was committed even by Latreille: "Le métathorax des pentatomes, des scutellères offre inférieurement une paire de stigmates" (RègneAn. nouv. éd. iv. p. 294, footnote).

The venerable Léon Dufour treated the matter far more

* It is of still less use to consult the general manuals in comparative anatomy, as all they contain in this respect concenning the structure of Insecta and Articulata in general is a confused mixture of a little that is true and a great mass of error; and no one has undertaken to verify the statements and view them from a more comprehensive morphological point of view. This holds good even with regard to the manual of Siebold, to whom, however, no blame attaches, as a better result could not be attained without new and comprehensive investigations. 
thoroughly in his highly meritorious and hitherto unique, though now in a great measure antiquated, work on the Rhynchota. He sums up the result of his conscientious investigation in these words:-- "Appareil respiratoire formé de stigmates toujours placés à la paroi inférieure du corps ...; une paire de stigmates pectoraux, quatre, six ou sept paires de stigmates abdominaux" (Rech. Anat. et Physiol. sur les Hémipt. p. 278). This statement is put forth as being valid with regard to all Rhynchota. The only pair of spiracles of the thorax which he knows is placed between mesothorax and metathorax (p. 235); in some cases, however, he simply denies the existence of any spiracles on the thorax, as with regard to Nepce, concerning which he says :- "C'est un fait incontestable que la Nèpe et le Ranatre n'offrent aucune trace de l'existence de stigmates thoraciques" (p. 245). With regard to the abdominal spiracles he specifies his general statement thus, that the common number is six, but that Miris and Capsus have seven pairs. He mentions this as "un trait anatomique fort remarquable" (p. 243); but he considers it still more remarkable that the female of Coreus (Syromastes) marginatus (L.) has seven pairs, whilst the male has only six; and in treating of the lateral part of the last abdominal segment of the female, he exclaims:- "Mais ce qu'il y a de fort remarquable dans ce repli, c'est qu'il est stigmatifère : en sorte que la femelle de cet insecte a une paire de stigmates de plus que le mâle" (p. 206). In Nepa he finds abdominal stigmata only in the third and fifth segments - that is, three pairs in all besides the respiratory tubes, which he considers morphologically separate organs, "indépendant des segmens propres de l'abdomen " (p. 246).

Against these statements concerning Nepa, Burmeister observes (Handb. d. Ent. ii. p. 197) that, with regard to the thorax, he cannot fully endorse them, because he has found a pair of spiracles between the metanotum and the first dorsal segment of the abdomen. It escaped Burmeister's attention that Léon Dufour had both described (p. 256) and figured (fig. 196,e) this organ, although he had refused to put it in a line with the ordinary spiracles and described it as a "sachet utriculaire." For the rest, Burmeister justly observes that, as these animals fly, they must have spiracles on the thorax; and he modestly adds that, inasmuch as it is well known how very difficult it is to observe these, they might exist in Nepa, although so able an anatomist as Léon Dufour had been unable to find them. Burmeister himself had several years before (Handb. d. Ent. i. p. 174) indicated the existence of a pair of spiracles between the prothorax and mesothorax in Rhynchota; and it seems 
therefore that afterwards, when the second volume of his manual was published, he did not wish to maintain his former statement as universally correct.

According to my own very extensive investigations, the facts are the following.

Rhynchota heteroptera possess, without exception, ten pairs of spiracles; and their distribution is exactly the same which I have demonstrated long ago in Eleutherata.

The first pair is placed in the connecting membrane between the prothorax and mesothorax. It is in most cases to be found only with great difficulty, and only by a very careful and skilful investigation. It very easily escapes attention on dried specimens, as it cannot be seen till the prothorax is taken away; but in this process the connecting membrane between the segments generally breaks in the very line of the spiracles, which therely become so lacerated that the remains of their peritrema can only with the greatest difficulty be recognized on the margins of the broken membrane. The proper way of demonstrating these spiracles is to disarticulate the first and second pair of legs, cut out the prosternum and mesosternum together, and then continue the dissection from above; when the vertral surface is cleared, more and more of it is cut away until the connecting membrane is isolated. The same proceeding may be used on dried specimens by first boiling them a couple of minutes, or longer, according to the size of the specimens.

The second pair of spiracles is rightly described by earlier authors; it is hidden behind the seam between meta- and mesothorax, and is visible only when the animal exerts itself in flying or running. In Nepe and Belostomata, where its existence has hitherto been denied by all, it is nevertheless in its ordinary place and of considerable size. The reason why it has hitherto escaped detection is, that these animals possess a very remarkable arrangement to prevent the entrance of the water, the epimera of the mesothorax being continued in the shape of a lamelliform cover, reaching beyond the metathorax to the base of the abdomen. This has not been observed; and the spiracle has been sought in vain because entomologists have sought it under the edge of this cover, which has been mistaken for the suture between the two segments, instead of looking for it under the real suture. This latter is not to be seen before the cover is removed to a little way in front of the second pair of coxæ, when the spiracle appears very clearly. It is only near its edge that the cover is closefitting ; further forwards the metathorax is so much inflected as to leave a considerable air-reservoir between it and the 
cover outside the spiracle. It is easy to see the importance of these arrangements for the respiration of the Nepoe. They come to the water flying, no doubt after long-continued search, and with the walls of the thorax violently distended by the exertion of the thoracic muscles; and in the same moment that the water closes over them they must dispense with the means of respiration of which they made use during flight. It is therefore a matter of the greatest importance to them to be able under all circumstances, merely by closing the covers formed by the metathorax, to get time to recover without danger of suffocation; they are thus rendered independent of the surrounding medium, until they can begin to make use of their respiratory tube. Something similar must hold good with regard to Belostomata, though their respiratory system is otherwise so different from that of Nepce; but nothing further is known with regard to the circumstances of life of these tropical animals.

The third pair of spiracles is placed on the back of the animal, hidden by the wings, between the metanotum and the first dorsal segment of the abdomen. It has hitherto only been observed in Nepae, as stated above, but exists really in all Heteroptera. It is large, and those who are sufficiently conversant with the structure of spiracles will not fail to see it; but others will easily be deceived by the various membranes which are placed between the places of insertion of the wingmuscles and the roots of the ribs of the wings. This is the pair which I have called spiracula metathoracica in Eleutherata, giving to the two anterior pairs the names respectively of spiracula prothoracica and mesothoracica; and in the choice of this name I have been guided by the fact that this third pair of spiracles does supply the metathorax with tracheæ. It seems to me that no more striking proof of the justice of this view can be demanded than the fact that these spiracles, together with that dorsal segment which is situated behind them, are moved forwards to join the thorax when the abdomen becomes pedunculated.

The fourth and following pairs, including the tenth, are placed on the ventral side of the pleural fold of the abdomen. There are consequently seven pairs of abdominal spiracles; and that entomologists hitherto have only known of six pairs, or in some cases of one pair more in the female, has a double cause. In the first place, the projecting posterior margin of the metathorax covers, in many trochalopodous bugs, as we have shown, a greater or smaller part of the first abdominal segment, together with the spiracles of this segment, which in that case do not become observable till this marginal plate Ann. \& Mag. N. Hist. Ser. 4. Vol. vi. 
is removed. In the second place, a collision arises between the exigencies of the seventh pair of spiracles and the modification of the last abdominal segment for the purposes of generation, in consequence of which the spiracle often is soeffectually hidden out of sight that it is not observed till the segment is entirely lifted out. In the females the pleural fold remains broader than in the males; and it must therefore be accidental, or perhaps rather owing to a want of perception of the general law, that Léon Dufour saw it only in the female of Syromastes marginatus and not in those of other Cimices and Corei in general. But in the males the last ventral segment is made use of for the organs of copulation to a much greater extent; and the pleural fold is so much reduced in extent that, as stated, the spiracle quite disappears from view and is not seen till the middle part of the segment is entirely taken out of its connexion; but with proper attention it can then always be seen. That Léon Dufour only saw it in Capsus and Miris was because the last abdominal ring is more moveable in these genera than in all other Heteroptera.

A more detailed account of the structure of the organs of respiration would be beyond the scope of the present treatise; and I shall therefore confine myself on this occasion to a short notice of a few points which are too closely connected with the preceding to be entirely passed over in silence.

The abdominal spiracles are round and open in all bugs living in the atmospheric air; but in those which live under water, they are partly modified in various ways, partly accompanied by special arrangements. In Nepoe the first two and the penultimate pairs are exceedingly small and apparently closed; the third, fourth, and fifth pairs very large, but closed by a plate presenting the appearance of a sieve, whilst the seventh is prolonged into a pair of air-tubes. The extremely remarkable structure of the large spiracles, however, as well as of the two which are situated behind the prothorax and behind the metanotum respectively, has not yet been properly demonstrated, and requires a nev and thorough investigation. On the present occasion I shall only mention this essential fact, which is of importance for the following, that from the seventh pair (the respiratory tubes) two large trunks of tracheæ run through the whole length of the body*. In

* Comp. Lóon Dufour's celebrated and often-copied figure 196 in 'Rech. Anat. et Physiol. sur les Hémipt.' ; it gives a good elementary view of the arrangement, but is, as will appear from the preceding observations, very inaccurate and incomplete as far as the whole fore part is concerned, where the author has accommodated it in accordance with his assertion that the thorax is entirely without spiracles. 
all the pagiopodous water-bugs all the spiracles of the abdomen are uniform and open, but turn their openings outwards and backwards, not downwards, in consequence of which they are difficult to find, unless the ventral surface is carefully examined in this very slanting position; outside them the pleural fold bears either an aëriferous border of hair (Notonecter, where these borders, in connexion with the keel of bristles along the ventral surface, form a complete roof over the layer of air), or of short close felt (Belostomata), or else the whole ventral surface is closely covered by short felt (Naucoris, Corixce) ; and from each spiracle a large trunktrachea proceeds to the interior, whilst the two large longitudinal trunks characteristic of Nepoe are here wanting.

Mistakes with regard to the spiracles of the abdomen have often been caused by the occurrence in most bugs of a series of impressions, sometimes having the appearance of short lines, sometimes of slightly impressed spots of a lighter colour than the surrounding ventral surface, sometimes of more or less deep points, which series is placed alongside the row of real spiracles, in most cases inside it, sometimes outside, or there may even be a row of impressions on each side of the row of spiracles. Inasmuch as these impressions, owing to their size and their colour, stand out in stronger contrast to the ventral surface than the spiracles, they have often been mistaken for these, though the absence of an opening, or of any thing that might be taken for the peritrema of the spiracles, easily convinces an attentive observer of the true nature of these impressions. These correspond to protuberances on the inside of the segments, which serve as points of attachment for a very complicated apparatus of ligaments and muscles whereby the trunk-tracheæ which spring from the spiracles are closed and opened.

\section{VI.}

In the foremost part of the abdominal cavity of Heteroptera two large, orange-coloured glandular sacs are observed, the odoriferous glands. Their secretion, an ethereal oil, is the source of the peculiar penetrating smell which is so well known from the common bug, but which in many other species is rather to be described as aromatic than as disagreeable. Léon Dufour has described the main features of these glands in several genera. I shall here confine myself to noticing their external apparatus, which in several cases, as already mentioned, have been mistaken for spiracles. The two ducts open on the metathorax. A distinction must be made between the spout with which the opening is often fur- 
nished, the spout-groove, which sometimes occurs as a continuation of the spout, and, finally, the evaporating-surface, which surrounds the opening and is intended to retain the secretion while it evaporates, and to prevent it from running down over the neighbouring parts, particularly the second pair of spiracles. To this end the surface is very finely granulated, and at the same time undulated-rugose. In the detail of their structure these parts exhibit so many varieties, that they are often of importance for the systematic diagnosis of the animals; and as they have hitherto been very little noticed, a general account of their distribution and principal forms will be of use. I shall principally take the examples from among the Danish species, which are quite numerous enough (more than three hundred species are known from Denmark).

In the family of Cimices there are some in which there seems to be no external indication of a glandular apparatus; amongst the Danish genera, Phimodera and Odontoscelis are in this case. In the others the opening is always situated on the side, at a greater or smaller distance from the coxæ, but exhibiting many varieties as to size, shape, spout-groove, and evaporating-surface. In Tetyra hottentotta and maura the opening is at a distance both from the coxæ and from the anterior edge of the metathorax; it is very narrow, and has a long straight groove, with narrow and sharply raised edges, and terminating with a sharply defined rounded outline; the evaporating-surface extends only to the metathorax, but is very large, surrounds the whole apparatus, and is externally bounded by a sharply defined arched line. Coreomelas and Legnotus have a highly developed, long, raised sprout-groove, extending along the suture of the mesosternum, and terminating in L. picipes with a projecting tooth; the evaporating-surface is very large, and extends backwards, more or less sharply defined, over the metasternum, covers the whole suture of the mesosternum, reaches some distance beyond the mesosternum, and sends a continuation forward along the margin of the elytra. In Podops, AElia, Cimex melanocephalus, vernalis, and baccarum, the opening is small, lateral, without a proper spoutgroove; the evaporating-surface is extensive, and forms an oval spot which covers the suture between metasternum and mesosternum. In Strachia and the other members of the same group the opening is nearer to the coxæ, there is no spout-groove, the evaporating-surface is small, and does not stretch so far inward as to reach the metasternum. The other Danish species of Cimices have a well-developed, long spout-groove, of which the external extremity is specially 
observable in C.pinicola, prasinus, nigricornis, and rufipes, on account of its black colour, whilst the sternum is green; the evaporating-surface in all these species is very large, and reaches so far as to occupy part of the mesosternum.

A similar arrangement to that of these species of Cimex is seen in Acanthosoma; the extremity of the spout-groove projects considerably in $A$. lituratum, which at the same time is distinguished from the other Danish species of this genus by a remarkable round black spot on the green chest, immediately under the point of the spout-groove. Asopus, too, has a long spout-groove, but the evaporating-surface is here very small and restricted to the metathorax; at the same time both it and the spout-groove vary according to the species. The spoutgroove is of a red colour, with a metallic-green point in A.bidens, whilst the underside of the thorax is yellowish grey, with black spots; in the other species the groove has the same colour as the chest generally, with a black spot in A.luridus before the point; the groove reaches as far as the anterior edge of the metathorax in A. sanguinipes, but terminates in our other species before reaching the margin; it is short and straight in $A$. punctatus, long and curved in the others; in $A$. punctatus only the anterior border is raised, whilst in the others both margins are swollen; in A.bidens the fore margin is twice as thick as the posterior margin; in the others the two margins are equal. The evaporating-surface is of a dull black, whilst the chest is of a metallic green, in $A$. coruleus; in the other species it is of the same colour as the chest: it reaches entirely round opening and spont in A. luridus and A. bidens; but in the other species it only covers the space immediately inside the opening of the duct, and is continued from there a shorter or longer distance outwards along the sides.

In Corei the opening is situated nearer the coxæ, or even in the middle of the sternum, between the posterior and the second pair of coxæ. In Syromastes and Coreus it is lateral, turned outwards, forming a short, widely open split, with very raised margins, and without a spout-groove; the evaporatingsurface is not plainly circumscribed, it surrounds the opening, and has a narrow prolongation on the mesothoracic suture. In Pseudophloeus nubitus the opening is close to and in a line with the second pair of coxæ, is long, wide open, with highly raised borders, and a projecting, very short spout-groove broadly rounded at its extremity; the evaporating-surface is not plainly defined, and occupies both sides of the mesothoracic suture. In Alydus the large oblong opening is placed on the sternum close in front of the third pair of coxæ; it has 
sharply defined, highly raised edges, but no spout-groove; the evaporating-surface forms a narrow ring round the opening and a small spot in front of this. In Corizus crassicornis the opening, which is placed far inwards on the sternum, is exceedingly small and difficult to find, punctiform, without spout-groove or evaporating-surface; whilst our other species of Corizus have a large, wide opening between the coxæ, without spout-groove, the evaporating-surface forming a narrow sharply defined strip covering both sides of the suture between meta- and mesothorax, of which latter the edge is finely and shortly pectinato-dentate. Our two species of Chorosoma agree in this respect with Corizus crassicornis. In Berytus the evaporating-surface is very large, quadrangular, reaching the mesosternum, and behind sharply separated from the arched epimeron; the opening is small, situate on the sternum, has in $B$. crassipes and clavipes no spout-groove, but in the other species a long, curved, sharply defined groove, terminating externally in B. elegans with a tooth. In Aradi and Tingidoe the opening, wherever I have succeeded in discovering it, is exceedingly small, punctiform, destitute of spout-groove or evaporating-surface.

In the family of Lygai there is less variety. The opening of the duct is generally near to the second pair of coxæ. In Cymus glandicolor and Caricis it is oval, the edges projecting, almost forming a tube, and externally prolonged into a short spout, but there is no evaporating-surface; in Cymus didymus, on the contrary, the spout is continued into a long groove, terminating in a point which projects from the body like a dagger, and the entire under surface of the thorax is developed as evaporating-surface. Chilacis agrees more nearly with the two preceding species of Cymus, except that the margin of the opening is very little raised. In Nysius the opening forms a long slit, with highly raised margins and short rounded spots; the evaporating-surface occupies the entire side of the metasternum, excepting the borders. In Phygadicus and Lygous the form of the opening is as in Nysius, but there is no evaporating-surface. The numerous species of Rhyparochromus vary but little amongst themselves: the opening with its short spout is generally slightly curved, and but little raised above the general surface of the body; and the evaporating-surface forms an indistinctly defined, almost quadrangular spot on the side of the metasternum; only in the group of Stygnocoris the opening is more round, with tubiform projecting margins and very short spout. In Geocoris the opening is oblong, with highly raised margins, but the evaporating-surface is confined to an indistinctly 
defined ring round the opening. Ischnodemus is distinguished by a lateral opening situated on an elongated protuberance, of which the margin projects outwards round a long pointed spout, which is considerably raised; the evaporating-surface is as in Rhyparochromus.

Hydrometroe and Nepa seem to be entirely destitute of odoriferous glands; I have at any rate searched in vain for any external opening.

In Reduvii these organs are generally very little developed. It is exceedingly difficult to find the small punctiform openings of the ducts, which are placed in a small impression close in front of the posterior pair of coxæ ; and in many species of this family $I$ have sought them in vain. Only in Nabis the openings are shaped like a slit, and rendered still more observable by the existence of a slightly impressed, narrow spout-groove, which is continued, close in front of the posterior coxa, a little way upwards, on the side of the metasternum; but there are only slight vestiges of an evaporatingsurface.

On account of the considerable development of the second, and still more of the third pair of coxæ, in Pagiopoda, the lateral part of the metasternum becomes very narrow and pointed, and the place for the glandular apparatus therefore more confined. In Capsus the lower extremity of the side of the metasternum is occupied by a small evaporating-surface, which is generally bounded by a distinct transverse line, and in its middle exhibits the opening of the duct, with more or less raised margins, but very short spout. The variation in shape is but small; the groups of Pithanus and Melanocoris are distinguished by the considerable development of the margin. In Miris the opening varies more; but the evaporating-surface is generally less developed, and less sharply defined. In Miris, sens. strict., the posterior lip of the spout is continued into a short thick knob; but in the groups of Notostira and Leptopterna the whole of the short spout is considerably raised; in the group of Trigonotylus the opening is very fine, with short narrow spout-groove, of which the margins are very slightly raised; but the most remarkable arrangement is that of the group of Teratocoris, where the opening is still more minute, punctiform, and hidden between the last two pair of coxæ, in consequence of which it is difficult to discover, unless the coxæ of the second pair are removed: both groove and evaporating-surface are wanting. In Anthocoris, Xylocoris, and Acanthia, the whole of the metasternum is developed as an evaporating-surface; the opening is rather large, the spout-groove sharply and deeply cut, but 


\section{On the Morphology and Classification of Rhynchota.}

varying in shape and size; in Anthocoris it is short and straight; in the two other genera long and curved; in Acanthia it is raised in the shape of a leaf directed backwards, and receding as far as the suture of the mesonotum. In Myrmedobia and Microphysa the opening is small, groove and evaporating-surface slightly developed. Neither in Saldoe nor in Pelegoni, nor in the swimming Heteroptera, Notonectoe, Belostomata, Naucorides, and Corixce, have I been able' with certainty to discover any external opening which could be supposed to belong to the glandular apparatus, although this must exist at least in some of them. Corixce are more particularly accompanied by a very perceptible bug-smell, and I have convinced myself that the odoriferous glands exist in them; but I have not succeeded in finding their external openings.

\section{VII.}

In accordance with the preceding considerations, I propose the following classification :-

I. Genæ excavatæ, coxas primas excipientes.

[Coxæ posticæ cardinatæ, scrobiculis femoralibus instructæ.]

Subordo Homoptera.

II. Genæ integræ, a coxis remotæ.

Subordo HeTERoptera.

A. Coxæ posticæ acetabulatæ, rotatoriæ, scrobiculis femoralibus nullis : Trochalopoda.

a. Epimera metathoracica laminata, segmentum primum ventrale abdominis obumbrantia.

1. Antennæ basi obtectæ. Fam. 1. Cimices.

2. Antennæ totæ detectæ.

* Antennæ præoculares. Fam. 2. Corei.

**Antennæ infraoculares. Fam. 3. Lygaei.

$b$. Epimera metathoracica lamina ventrali carentes.

1. Unguiculi superpositi. Fam. 4. Hydrometra.

2. Unguiculi terminales.

* Epimera metathoracica maximam partem epimeris mesothoracicis obtecta. Spiracula abdominalia ultimi paris siphunculata. Fam. 5. Nepee.

* Epimera metathoracica tota detecta. Spiracula abdominalia æqualia. Fam. 6. Reduvii. 
Rev. W. A. Leighton on a new Genus of Lichens. 249

B. Coxæ posticæ cardinatæ, scrobiculis femoralibus instructæ : Pagiopoda.

a. Antennæ detectæ. Fam 7. Acanthioe.

b. Antennæ obtectæ.

1. Corpus depressum, pronum.

a. Rostrum liberum.

+ Epimera metathoracica detecta.

* Pedes cursorii. Fam. 8. Pelegoni.

* Pedes natatorii. Fam. 9. Naucorides.

计 Epimera metathoracica maximam partem epimeris mesothoracicis obtecta. Fam. 10. Belostomata.

$\beta$. Rostrum obtectum. [Epimera metathoracica detecta, appendiculata.] Fam. 11. Corixce.

2. Corpus naviculare, supinatum. [Epimera metathoracica detecta. Rostrum liberum.] Fam.12. Notonectoe.

XXIII.-Notula Lichenologica. No. XXXIII. By the Rev. W. A. Leighton, B.A., F.L.S., F.B.S. Edin.

In the 'Flora' of 1864, p. 487, Dr. Nylander proposed to place Endocarpon Guepinii, Delis., in a new genus, which he named Endocarpiscum, on account of the thallus containing " granula gonima." Dr. Hepp had previously arranged this lichen in a a new genus, Guepinia, because the asci were polysporous. But as Guepinia had already been appropriated by Fries to a genus of the Hymenomycetous Fungi, the name could not be used amongst Lichens.

Recently Dr. F. Baglietto, in Nuova Giorn. Bot. Ital. vol. ii. p. 171, has instituted a careful microscopical examination of the fructification in its progressive stages, and finds that, although in an early stage it is pyrenocarpous, yet in maturity it becomes gymnocarpous, and expands into a perfect patellulate apothecium. On this account he proposes to constitute it a new genus, Guepinella, which he considers to be systematically near to the genus Heppia, Näg., in the family of the Peltigerei. He gives the following: diagnosis:-

\section{Guepinella, Bagl.}

Apothecia thallo primum inclusa, sensim aperta urceolatosaccata, demum perfecte discoidea a thallo elevato margi- 